\title{
Vývoj povrchu holé orné půdy s využitím stereofotogrammetrie
}

\section{TOMÁŠ LABURDA, JOSEF KRÁSA, MARTIN FLORIAN, MONIKA MACHÁČKOVÁ}

Klíčová slova: půdní povrch - drsnost - konsolidace - stereofotogrammetrie - eroze půdy

\section{SOUHRN}

Příspěvek se zabývá vývojem půdního povrchu bez vegetace pomocí metody stereofotogrammetrie. Popisuje a porovnává změny půdních vlastností na čtyřech typech kultivace půdy. Vyhodnocení je zaměřeno na změny drsnosti půdního povrchu a konsolidace $v$ důsledku prirozeného sesedání, působení deštových srážek a vysychání.

Pro každý druh obdělávání bylo vytvořeno pět experimentálních ploch na zemědělském pozemku u obce Červený Újezd ve Středních Čechách. Experimenty byly prováděny ve dvou etapách od podzimu do jara roku 2015/2016. Hlavním cílem bylo především pokrýt období, ve kterém se na zemědělských pozemcích vyskytují holé půdy bez vegetačního pokryvu. Výsledky ukazují velkou závislost měřených veličin především na př́valových srážkách, které se na experimentálních plochách vyskytly v říjnu 2015 a predevším v květnu a červnu roku 2016. Největší změny byly zaznamenány na plochách zpracovaných pomocí pluhu, které již od počátku měření dosahovaly nejvyšších hodnot drsnosti půdního povrchu a zároveň byly zpracovány do největší hloubky.

\section{ÚVOD}

Eroze půdy je dlouhodobý problém nejen v ČR, kde je stále ohroženo až 50 \% zemědělské půdy erozí vodní a téměř $10 \%$ erozí větrnou [1]. Na výskyt vodní eroze mají vliv především geomorfologické a pedologické podmínky, výskyt a rozložení srážek a svůj nezanedbatelný vliv má také zemědělská produkce, která značně ovlivňuje a mění vlastnosti půdy během roku. Množství smyvu v erozním odtoku je závislé nejen na uvolnění částic půdy srážkou, ale rovněž na rychlosti povrchového odtoku a vznikajícím tečném napětí na povrchu pưdy. Rychlost proudění i retence vody na půdním povrchu jsou prímo závislé na jeho drsnosti [2]. Pro výzkum drsnosti povrchu půdy byl vytvořen tento experiment, který má za úkol popsat vývoj holé půdy po provedení různých druhů kultivace. S využitím stereofotogrammetrie byl popsán vývoj povrchu zemědělské půdy pod vlivem přirozených deštů a přirozeného sesedání v časové raadě od provedení kultivace. Experiment se zabýval vývojem čtyř různých úprav povrchů půdy, které vznikly odlišnými technologiemi zpracování ve dvou různých časových řadách od podzimu roku 2015 do jara roku 2016.

Způsob výpočtu eroze pomocí Revidované univerzální rovnice ztráty půdy (RUSLE) byl motivací k tomuto experimentu [2]. RUSLE oproti původní a dosud nejčastěji uživané metodě výpočtu erozního smyvu pomocí Univerzální rovnice ztráty půdy (USLE) [3] zahrnuje mimo jiné do svého výpočtu vliv drsnosti půdního povrchu, který se s časem po kultivaci mění [2].

Tento vliv je zahrnut ve výpočtu C faktoru, který dále zahrnuje subfaktory popisující vliv zakrytí povrchu porostem, půdního pokryvu, predchozího využívání pozemku, vlhkosti půdy a drsnosti půdního povrchu. Samotný subfaktor drsnosti závisí mimo jiné na provedené technologické operaci (druhu kultivace) s experimentálně určenou počáteční drsností, která se pod vlivem deštových srážek s časem snižuje [2].

Pro půdy a klima v podmínkách střední Evropy však kalibrační data parametru počáteční drsnosti půdního povrchu chybí a používají se hodnoty uvedené v [2]. To, jakým způsobem a jak se drsnost půdního povrchu mění pro konkrétní způsoby kultivace půdy, je předmětem prezentovaného výzkumu, který může přispět k revizi těchto hodnot a tím i zpřesnění výpočtu eroze pưdy ve středoevropských podmínkách.

\section{METODIKA}

Hlavní cíle a úkoly tohoto výzkumu byly stanoveny ve spolupráci s vědci z rakouské instituce BAW-IKT (Federal Agency for Water Management Austria, Institute for Land and Water Management Research), kteří se zabývají výzkumem půdy a vodního hospodářství. Ti zároveň provádí podobný výzkum poblíž rakouského města Petzenkirchen. Cílem jejich a našeho výzkumu je po ukončení experimentu spojit a porovnat získaná data, čímž bude tento výzkum obohacen o dalši sadu dat a výsledků.

Pro měření konsolidace a drsnosti půdy bylo využito stereofotogrammetrické metody, která má své výhody v tom, že neovlivňuje měřicí plochu, má v závislosti na použitém fotoaparátu vysokou přesnost v řádu milimetrů v každém směru a náklady na realizaci jsou relativně nízké (oproti např. laserové technologii) [4]. Základním principem této metody je vytvoření digitálního modelu terénu (DMT) ze snímků experimentální plochy. Snímků bylo pořizováno pro každou plochu celkem osm. Vždy byly pořizovány čtyři fotografie v šikmém směru (pod přibližným sklonem $45^{\circ}$ ) z každé strany referenčního rámu a další čtyři snímky (stereofotografie) byly foceny ze svislého směru z přibližné výšky $160 \mathrm{~cm}$. Jedná se vždy o dvě stereodvojice, které jsou navzájem na sebe kolmé (snímky ve stereo dvojici jsou od sebe vzdáleny cca $50 \mathrm{~cm}$ ) [5].

Pro parametrizaci půdní drsnosti byl z mnoha jiných parametrů zvolen náhodný index drsnosti (rrAR), který je nejběžněji využívaný [5]. Ten se vypočítá jako směrodatná odchylka výškových hodnot v logaritmickém měřítku, z nichž se následně odstraní $10 \%$ horních a spodních hodnot. Tento index je zakomponován také v RUSLE, kde jeho negativní exponenciální korelace mezi drsností půdního povrchu a půdní erozí vysvětluje efekt snížení drsnosti v čase.

Dalším sledovaným parametrem na začátku a na konci obou sérií měření byla objemová hmotnost a vlhkost půdy ovlivněné kultivací povrchu. Výzkum byl proveden rovněž v rámci zpracování diplomových prací studentky Moniky Macháčkové v roce 2015/2016 [6] a navazující práce studenta Martina Floriana $\checkmark$ roce 2016 [7]. 
A
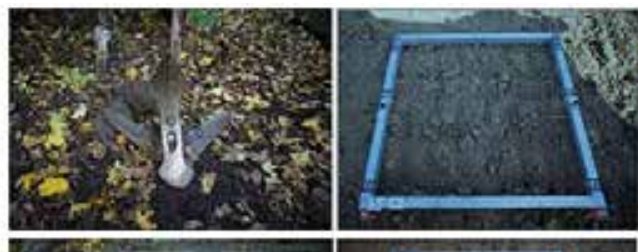

B
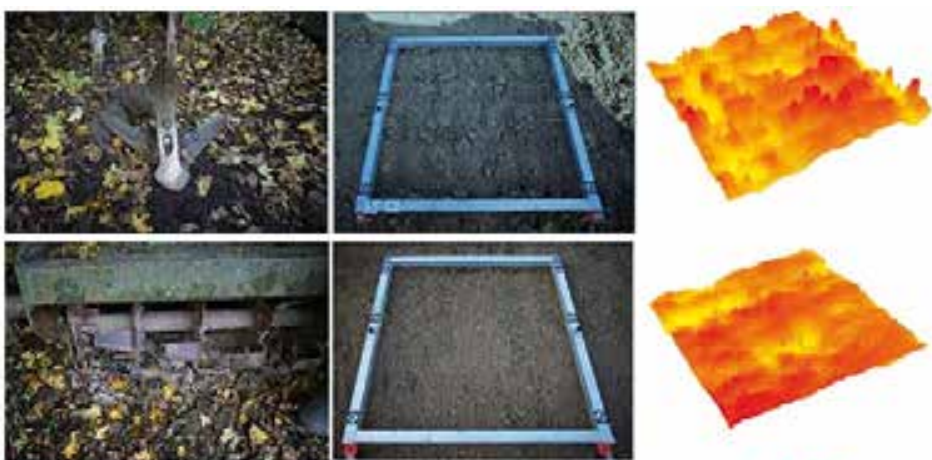

C
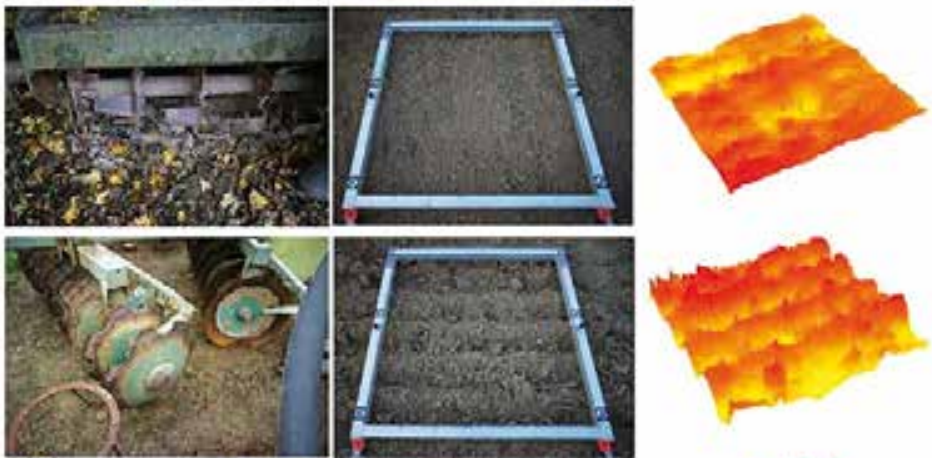

D
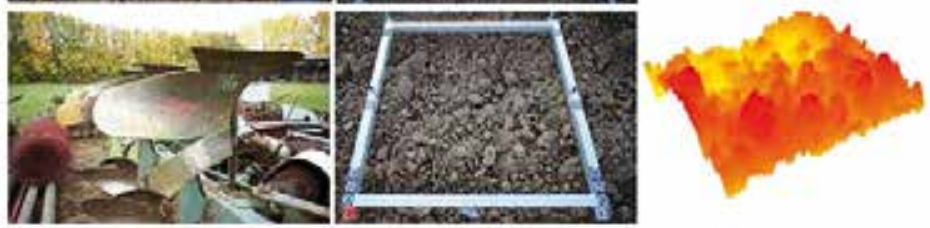

Obr. 1. Testované plochy A-D: použitá mechanizace obdělání - fotografie terénu 2x převýšený DMT [6]

Fig. 1. Experimental plots A-D: cultivation machinery - photography of soil surface Digital Elevation Model (vertical exaggeration of 2 times) [6]

\section{EXPERIMENTÁLNÍ MĚŘENÍ}

Měrení bylo prováděno na experimentálních plochách, které se nachází ve Středočeském kraji přibližně 10 km západně od Prahy u obce Červený Újezd na pozemcích, které vlastní Výzkumná stanice České zemědělské univerzity. Půdním typem se jedná o hnědozem. Terén je v oblasti rovinatý, a tedy zajištuje dobrý vsak srážkových vod. Půda je mírně až středně pórovitá (45-50\% objemu), obsahuje malé množství humusu (1-2\%), má nižší sorpční kapacitu (8-17 mmol+/100 g) a je slabě kyselá $(\mathrm{pH}=5,6-6,5)$. Průměrná nadmořská výška území je 405 m n. m. [6].

\section{Způsoby kultivace}

V rámci experimentu byly porovnávány čtyři druhy obdělávání půdy pomocí radličkového kypřiče (pole A), rotavátoru (kypřič s horizontálním rotorem) (pole B), taliřového podmítače (pole C) a pluhu (pole D), které se lišily kromě použité mechanizace také hloubkou zpracování (tabulka 1 a obr. 1). Pro každou z těchto úprav A-D bylo vytvořeno pět experimentálních ploch 1 až 5 .
Tabulka 1. Porovnáníhloubek zpracování pưdy

Table 1. Comparison of cultivation depth

\begin{tabular}{lll} 
Kultivace & 1. série $[\mathrm{cm}]$ & 2. série $[\mathrm{cm}]$ \\
\hline A - radličkový kypřič & 7,5 & 9,5 \\
\hline B - rotavátor & 8,6 & 11,8 \\
\hline C - talî̌ový podmítač & 4,9 & 10,0 \\
\hline D - pluh & 14,1 & 29,5
\end{tabular}

\section{Referenční rám}

K přesnému vyhodnocování změn na jednotlivých vzorcích půdy byl použit jednoduchý hliníkový referenční rám o rozměrech 1,2 ×1,2 m, který byl usazován na stále stejná místa pomocí železných tyčí nad jednotlivými experimentálními plochami. Na rámu jsou umístěny referenční terče o velikosti $5 \times 5 \mathrm{~cm}$, které slouží k určení místních souřadnic (viz obr. 2).
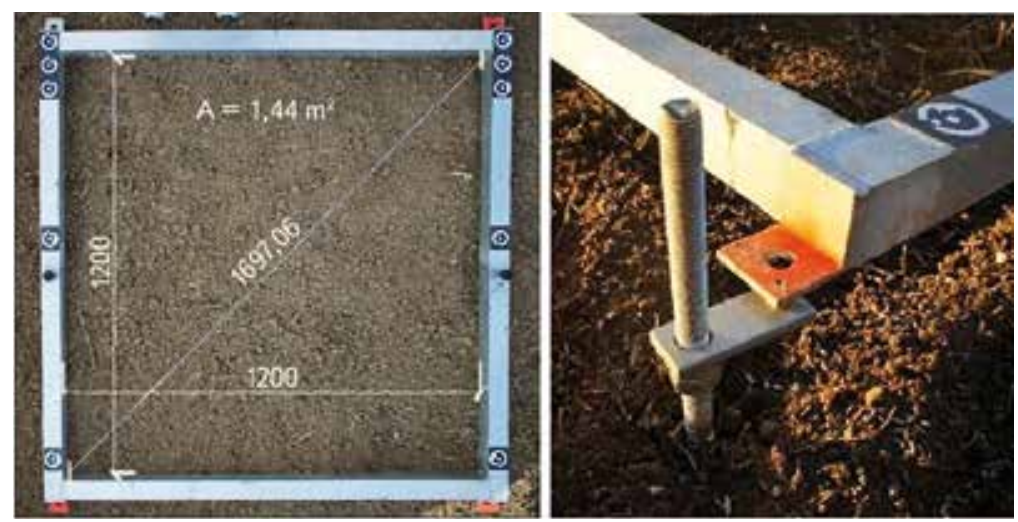

Obr. 2. Referenční rám a způsob jeho uchycení na testovanou plochu [6] Fig. 2. Reference frame and its fixation above experimental plots [6]

\section{Série měření}

Pro popis vývoje konsolidace a drsnosti půdy byly provedeny dvě série měření. Každá série zahrnovala měření v určitých časových intervalech, které se od počátku kultivace povrchu postupně zvětšovali s tím, jak se změna drsnosti či konsolidace postupně zpomalovala. Přibližný časový odstup byl 0-1-3-5-7-7-14-14-21-21 dní, přičemž pokud se nad místem vyskytla významná srážková událost, bylo měření provedeno následující den. Seznam provedených měření je uveden v tabulce 2. Pro měření byl použit fotoaparát SONY NEX-5N, 5R (rozlišení 16,1 Mpx) a A-6000 (rozlišení 24,3 Mpx) s objektivem SONY s pevným ohniskem $16 \mathrm{~mm}$ a zoomem 18-55 mm. Pro každou kombinaci fotoaparátu a objektivu byly vytvořeny kalibrační soubory, které slouží k vyloučení vzniklých optických deformací snímku. 
Tabulka 2. Seznam provedených měřeníběhem 1. a 2. série experimentů Table 2. List of data collecting during ${ }^{\text {jt }}$ and $2^{\text {nd }}$ stage of measurement

\section{1. série}

\begin{tabular}{|c|c|c|c|c|c|}
\hline & Datum & $\begin{array}{l}\text { Časový } \\
\text { odstup [dny] }\end{array}$ & & Datum & $\begin{array}{l}\text { Časový } \\
\text { odstup [dny] }\end{array}$ \\
\hline 0 & 24. 9. 2015 & instalace ploch & 0 & 21. 4.2016 & instalace ploch \\
\hline 1 & 24. 9. 2015 & 0 & 1 & 22. 4. 2016 & 1 \\
\hline 2 & 25. 9. 2015 & 1 & 2 & 26. 4. 2016 & 4 \\
\hline 3 & 28. 9. 2015 & 3 & 3 & 29. 4. 2016 & 3 \\
\hline 4 & 1. 10. 2015 & 3 & 4 & 9.5 .2016 & 10 \\
\hline 5 & 9. 10. 2015 & 8 & 5 & 24. 5. 2016 & 15 \\
\hline 6 & 16. 10. 2015 & 7 & 6 & 10. 6. 2016 & 17 \\
\hline 7 & 2. 11. 2015 & 17 & & Celkem & 50 \\
\hline 8 & 23. 11. 2015 & 21 & & & \\
\hline 9 & 9. 12. 2015 & 16 & & & \\
\hline 10 & 14. 1. 2016 & 36 & & & \\
\hline 11 & 29. 1. 2016 & 15 & & & \\
\hline 12 & 24. 2. 2016 & 26 & & & \\
\hline \multirow[t]{2}{*}{13} & 19. 4. 2016 & 55 & & & \\
\hline & Celkem & 208 & & & \\
\hline
\end{tabular}

Celkem bylo provedeno a vyhodnoceno 13 experimentů z 1. série měření a 6 experimentů z2. série. To zahrnovalo vyhodnocení celkem 380 dílčích ploch s celkovým počtem 3040 snímků.

Během provádění experimentů byla sledována také data ze srážkoměrné stanice umístěné $v$ rámci Výzkumné stanice ČZú, které poskytl Ing. Pavel Cihláŕ, Ph.D. Celkový úhrn srážek během 1. série měření byl 223,0 mm (během prvních srovnatelných a zde prezentovaných 60 dní to bylo $89,2 \mathrm{~mm}$ ) a 103,5 mm během 2. série experimentů. Více než celkové úhrny jsou však důležitější maximální hodinové a denní srážkové úhrny, které se nad daným územím vyskytovaly především v jarních měsících. Zatímco během 1. série měření dosáhly maximální hodnoty 21,1 a 13,8 mm/24 hod, během 2. série to bylo 48,4 a 26,4 mm/24 hod.

\section{VYHODNOCENÍ}

Základní postup vyhodnocení snímků zahrnoval vytvoření bodového mračna pomocí softwaru PhotoModeler Scanner. Každé mračno bodů popisuje povrch nafoceného terénu pomocí souřadnic $X, Y$ a $Z$ s počátkem ve středu jednoho z referenčních terčů na rámu. Tato mračna byla dále zpracovávána v programu ArcMap 10.3, kde z nich byly vytvořeny výsledné DMT (viz obr. 7) s velikostí pixelu $1 \mathrm{~mm}$ nad plochou $1 \times 1 \mathrm{~m}$ uvnitř referenčního rámu. Výsledný počet bodů nad touto plochou se pohyboval približně od 800000 do 1000000 bodů v případě fotoaparátu SONY NEX-5N a přibližně od 1400000 do 1600000 bodů při použití SONY ILCE-6000. Tyto DMT jednotlivých ploch byly dále vyhodnocovány a porovnávány mezi sebou.
Mezi hlavní dvě sledované veličiny patří drsnost půdního povrchu a konsolidace. Drsnost půdního povrchu je reprezentována jako směrodatná odchylka skutečné výšky terénu od průměrné výšky stejně, jako je tomu při výpočtu subfaktoru drsnosti v RUSLE. Konsolidace půdy je uvažována jako pokles průměrné výšky povrchu terénu na sledované ploše $1 \times 1 \mathrm{~m}$. Vzhledem ke stručnosti tohoto přispěvku zde prezentované výsledky sledují vývoj průměrné drsnosti a konsolidace ze všech pěti testovaných ploch z každého způsobu obdělávání A-D. $\checkmark$ diplomových pracích studentů bylo porovnání provedeno i v rámci jednotlivých testovaných ploch 1-5.

\section{Konsolidace půdy}

Výsledky na obr. 3 ukazují průběh konsolidace během 1. série experimentu. Z grafu je patrné, že nejvyšších změn dosahují všechny testované plochy s príchodem prvních deštư, tj. mezi dny 10-12 a následně mezi dny 17-22. Tento výrazný pokles je způsoben především vysokým úhrnem srážek, kdy za tuto dobu spadlo 50,8 mm z celkových 89,2 mm, tj. cca 57 \% celkového úhrnu.

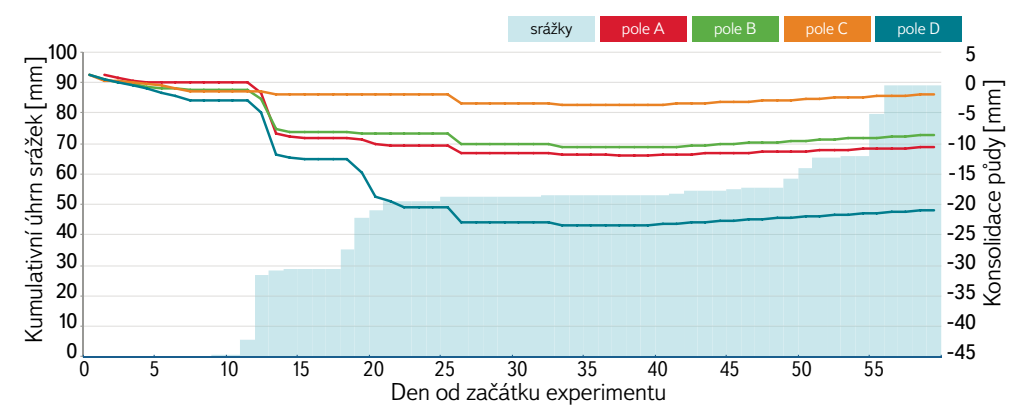

Obr. 3. Konsolidace půdy - experiment 1 [7]

Fig. 3. Soil consolidation $-1^{\text {st }}$ stage [7]

Obrázek 4 zobrazuje průběh konsolidace během 2. série experimentu. Z grafu je opět patrný skokový pokles půdy po prívalovém dešti okolo 31. dne, kdy celkový úhrn dosáhl 48,4 mm/24 hod. Následně stejná situace se opakuje mezi 38.-42. dnem, kdy došlo k úhrnu 26,4 mm/24 hod.

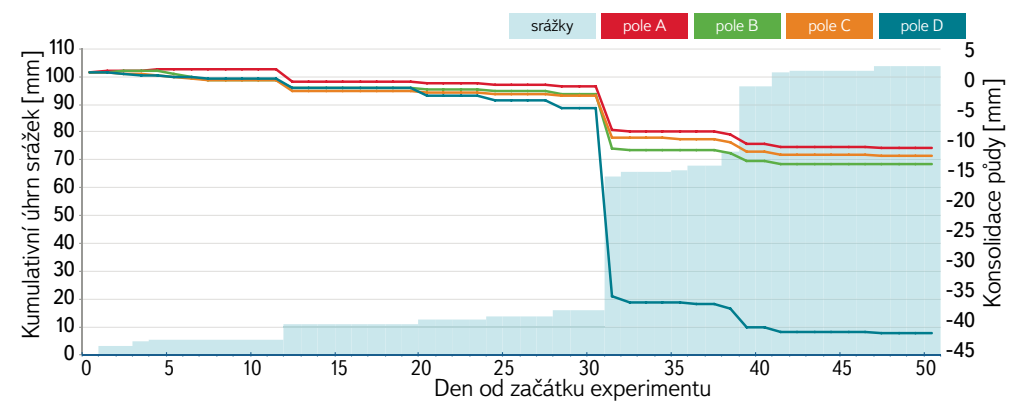

Obr. 4. Konsolidace půdy - experiment 2 [7]

Fig. 4. Soil consolidation $-2^{\text {nd }}$ stage [7]

Z hlediska porovnání ploch podle kultivace je zřejmé, že k nejvyšší změně dochází u půdy zpracované pomocí pluhu. To je způsobeno především hloubkou zpracování půdy (hloubka nakypření), která byla v obou sériích nejvyšší právě u plochy $D$ a dosahovala přibližně 14 a $30 \mathrm{~cm}$ oproti např. ploše $C$, kde byly tyto hodnoty pouze 5 a $10 \mathrm{~cm}$ (viz tabulka 1). Dalším důležitým faktorem ovlivňující konsolidaci je velikost a tvar vytvořených půdních agregátů a s tím související množství pórů ve svrchní vrstvě půdy. U plochy D zkultivované pomocí pluhu je právě velikost těchto agregátů nejvyšší a s tím i prostorů, kam se můžou rozpadlé částice uvolnit, a tím snižit prưměrnou výšku testované plochy. 


\section{Drsnost půdního povrchu}

Obrázek 5 zobrazuje průběh drsnosti půdního povrchu během 1. série experimentu. Stejně jako v prípadě konsolidace i drsnost povrchu je významně ovlivňována srážkami, které způsobují rozpad půdních agregátů na menší shluky půdních částic. Největší změny jsou patrné opět kolem 10. a 20. dne. Z hlediska počátečních hodnot dosahuje nejvyšší drsnosti pole D zkultivované pomocí pluhu, který za sebou zanechává největší půdní agregáty s velmi rozmanitým tvarem.

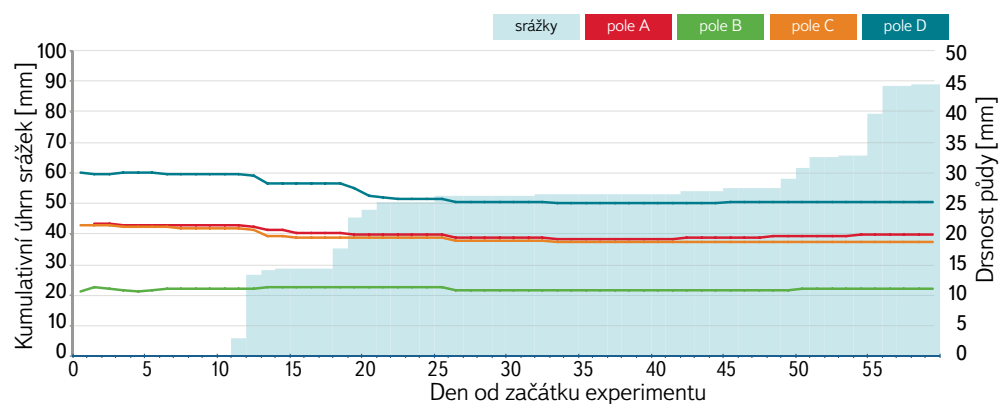

Obr. 5. Drsnost půdy - experiment 1 [7]

Fig. 5. Soil roughness $-1^{\text {st }}$ stage [7]

Stejná situace se opakuje i ve druhé sérii měření (obr. 6), kde k zásadní změně dochází opět okolo 31. dne, kdy došlo k velké srážkové události. Drobné odchylky je možné pozorovat i mezi 3.-10. dnem, kdy dochází k nepatrnému zvýšení drsnosti. To je podle autorů způsobeno použitím jiného fotoaparátu s vyšším rozlišením, tj. fotoaparátu SONY A-6000 s 24,3 Mpx namísto obvyklého fotoaparátu SONY NEX-5N s 16,1 Mpx, který v době několika experimentů nebyl z důvodu opravy k dispozici. Toto vyšší rozlišení fotoaparátu v důsledku vytvoří približně o 60 \% více bodů (viz kapitola Vyhodnocení), čímž dojde k vyššímu rozlišení terénních nerovností, které se při menším rozlišení neprojeví, a tím pádem ke zvýšení hodnot drsnosti.

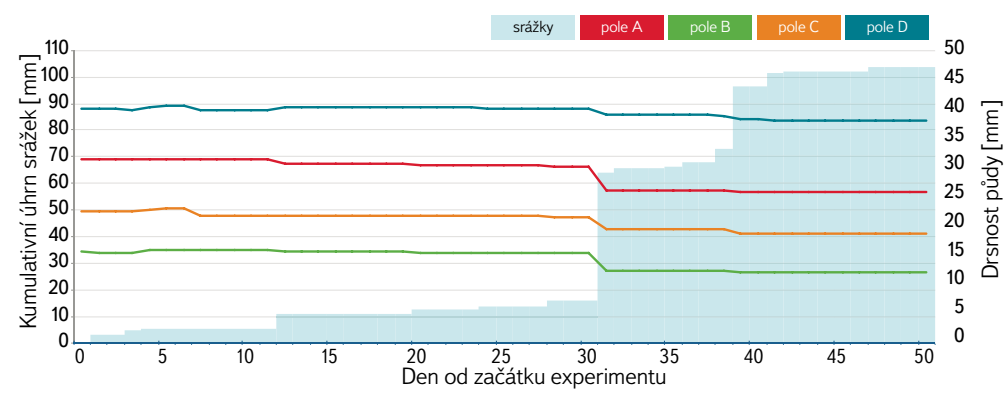

Obr. 6. Drsnost půdy - experiment 2 [6]

Fig. 6. Soil roughness $-2^{\text {nd }}$ stage [6]

Srovnání jednotlivých ploch A-D mezi sebou se v jistém ohledu podobá výsledkům konsolidace. Nejvyšších hodnot dosahuje drsnost u plochy D, kde kultivace pomocí pluhu za sebou zanechává největší půdní agregáty. To do jisté míry souvisí i s největší hloubkou záběru. Z hlediska porovnání ostatních způsobů kultivace, nejvíce podobných výsledků je dosaženo u ploch A a C, tj. kultivace pomocí radličkového kypřiče a talî̌rového podmítače. Použití rotavátoru u plochy B v obou prípadech za sebou zanechává nejhladší povrch s minimem nerovností.
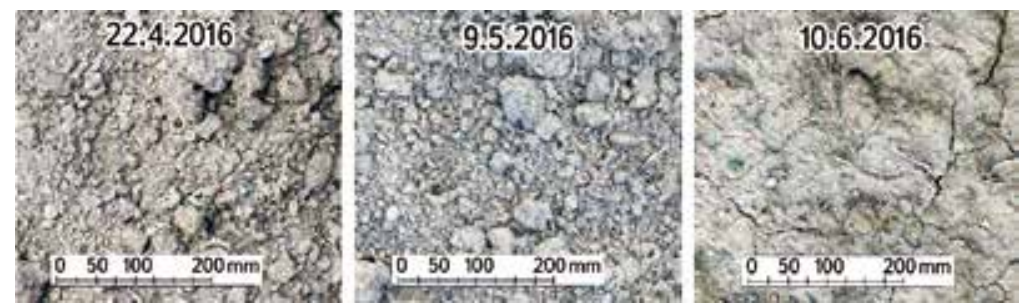

Obr. 7. Viditelné změny povrchu půdy na začátku a konci 2. série experimentů Fig. 7. Noticeable changes of soil surface between the beginning and the end of $2^{\text {nd }}$ stage of experiments

\section{ZÁVĚR}

Výzkum vývoje povrchu holé půdy bez vegetace přinesl výsledky, které ukazují, jak se testovaná půda chová v závislosti na počáteční úpravě povrchu a přirozených vlivech. Výsledky ukazují, jak konkrétní úprava povrchu půdy může přispět k zadržení vody v krajině a omezení vodní eroze. Z tohoto pohledu je možné jako nejméně vhodné zpracování označit kultivaci pomocí rotavátoru (pole B), kdy vznikne drobtovitá struktura s velmi jemnými částicemi, naopak jako nejvhodnějším se jeví zpracování půdy pomocí pluhu (pole D), kde vzniklé půdní agregáty tvoří významné prohlubně a překážky.

Dưležité je zmínit, že uvedené způsoby kultivace nejsou jedinými způsoby kultivace a často jsou mezi sebou provázány. To je příklad právě orby pomocí pluhu, po kterém běžně přichází na řadu úprava vláčením, při kterém se povrch přibližuje svými vlastnostmi povrchu upraveného např. pomocí rotavátoru.

Ze jmenovaných vnějších činitelů mají největší vliv na změnu vlastností povrchu půdy srážky, které způsobují největší změny z hlediska snižovaní drsnosti a tím i souvisejícím celkovým poklesem půdy.

Rozsáhlejší príspěvek bude po doplnění o data rakouských kolegů z BAW-IKT publikován během roku 2017.

\section{Literatura}

[1] JANEČEK, M. aj. Ochrana zemědělské pưdy před erozí. Praha: Česká zemědělská univerzita, 2012, 113 s. ISBN 978-80-87415-42-9.

[2] RENARD, K.G., FOSTER, G.R., WEESIES, G.A., MCCOOL, D.K., and YODER, D.C. Predicting Soil Erosion by Water: A Guide to Conservation Planning with the Revised Universal Soil Loss Equation (RUSLE). United States: Departement of Agriculture, January 1997, 407 p. ISBN 0-16-048938-5.

[3] WISCHMEIER, W.H. and SMITH D.D. Predicting rainfall erosion losses - A guide to conservation planning. Agriculture handbook no. 537. Washington: Departement of Agriculture, December 1978.

[4] GRIMS, M., ATZBERGER, C., BAUER, T., and STRAUSS, P. Low-cost Terrestrial Photogrammetry as a Tool for a Sample-Based Assessment of Soil Roughness Preiswerte terrestrische Photogrammetrie als Werkzeug zur Bestimmung der Rauigkeit von Böden. Photogramm.-Fernerkundung-Geoinf., Vol. 2014, No. 5, p. 313-323, 2014.

[5] BAUER, T., STRAUSS, P., GRIMS, M., KAMPTNER, E., MANSBERGER, R., and SPIEGEL, H. Long-term argicultural management effects on surface roughness and consolidation of soils. Soil \& Tillage Research, 2015, 151, p. 28-38.

[6] MACHÁČKOVÁ, M. Popis vývoje povrchu zemědělsképůdy s využitím stereofotogrammetrie. Diplomová práce. Praha: ČVUT, 2016, $111 \mathrm{~s}$

[7] FLORIAN, M. Popis povrchu orné pưdy s využitím stereofotogrammetrie. Diplomová práce. Praha: ČVUT, 2016, $106 \mathrm{~s}$. 


\section{Poděkování}

Tento výzkum byl podpořen projektem QJ1330118 - Monitoring erozního poškození půd a projevů eroze pomocí metod DPZ, projektem 7AMB14AT020 - Výzkum vlivu krajinné matrice na odtokový režim, erozní a transportní procesy a kvalitu půdy a projektem QJ1530181 - Stanovení aktuálních hodnot ochranného účinku vegetace za účelem kvantifikace a zefektivněni protierozni ochrany zemědělské půdy v České republice. Poděkování patři také doc. Ing. Milanu Kroulikovi, Ph.D., a doc. Ing. Václavu Brantovi, Ph.D., z České zemědělské univerzity v Praze za poskytnutí a prípravu experimentálních ploch a kolegům Dipl.-Ing. Thomasi Bauerovi a Dipl.-Ing. Dr. Peteru Straussoviz BAW-IKT za participaci na metodice měrení.

\section{Autoři}

Ing. Tomáš Laburda

凶tomas.laburda@fsv.cvut.cz

doc. Ing. Josef Krása, Ph.D.

凶josef.krasa@fsv.cvut.cz

\section{Bc. Martin Florian}

凶martin.florian@fsv.cvut.cz

Ing. Monika Macháčková

凶monika.machackova@fsv.cvut.cz

České vysoké učení technické v Praze, Fakulta stavební, Katedra hydromeliorací a krajinného inženýrství

Příspěvek prošel lektorským řízením.

\section{AGRICULTURE BARE SOIL SURFACE EVALUATION USING STEREOPHOTOGRAMMETRY}

\section{LABURDA, T.; KRASA, J.; FLORIAN, M.; MACHACKOVA, M.}

Czech Technical University in Prague, Faculty of Civil Engineering, Department of Irrigation, Drainage and Landscape Engineering

Keywords: soil surface - roughness - consolidation stereophotogrammetry - soil erosion

The article deals with the development of agriculture bare soil surface using the stereophotogrammetric method. It describes and compares the development of selected soil characteristics investigated on four types of field cultivation. It evaluates changes in the characteristics of terrain with an emphasis on surface roughness and consolidation under natural conditions.

Five experimental plots for each type of cultivation were created in the region of Central Bohemia near to village Červený Újezd. Experiments run in two repetitions in autumn and spring 2015/2016. The main goal was to cover months when bare soil is found in arable land. Results show strong dependence of soil roughness and consolidation on extreme rainfall events which occurred in October 2015 and mainly in May and June 2016. The highest changes in soil characteristics were measured on experimental plots cultivated by plough which had highest roughness and depth of cultivation at the beginning of experiments. 